\title{
Schooling, Symbolism and Social Power: The Hijab in Republican France
}

\author{
Joel Windle \\ University of Melbourne
}

\begin{abstract}
To fully understand the implications of the global climate of heightened suspicion about Islam we must also be aware of its expression through distinctive national discourses. Media debate leading up to the adoption by the French parliament of a law banning the hijab at school fits into a global discourse, but also presents local strategies of incorporation and silencing. The targets of scrutiny are primarily first and second generation migrants, a large and increasingly visible portion of whom live in rundown public housing and attend 'problem' schools associated with violence and failure. It is important therefore to consider the position, and positioning, of Muslims in relation to media representation. This article analyses the forms the dispute over the hijab has taken in France in terms of the role of the school in Republican ideology; the social and economic position of Muslims; and dominant representations of migrants and Islam.
\end{abstract}

\section{Introduction}

The current upsurge in debate over the place of Islamic symbols and practices in Australia, through the letters pages of major newspapers and from commentators (see, for example, Bone 2004), demonstrates the growing importance of Islam as a theme in the political imaginary. In a new age of fear about terrorism, and specifically 'Muslim' terrorism, a global discourse of suspicion about Islam is emerging. Diverse interests and distinctive forms interlock here, and our understandings of the implications of the transnational trend can benefit from an awareness of local inflections, which overlap to provide a global impetus.

This paper considers the distinctive rationale of the discourse in France, which has recently attracted international attention and comment. It analyses the debate over the wearing of the hijab ${ }^{1}$ in French government schools as an instance of conflict 
expressing historical and ongoing class struggles through the symbolic economy of French nationalism.

The issue, in its current form, emerged in France after the exclusion from school in 1989 of three students who arrived wearing the hijab, with confrontational incidents recurring as recently as September 2003 (for accounts see Limage 2000, Silverman 1992). In February 2004 legislation to strengthen the existing administrative directive effectively banning the hijab from state schools passed through parliament with near universal support (494 in favour, 31 abstentions, 36 against).

This paper discusses the national context of the debate and media texts gathered over the period April-June 2003. Public debate was at a high point during this period, which coincided with the election of the first Conseil Français du Culte Musulman (French Council of Islam), international fears over Muslim terrorism, domestic concerns about anti-Semitism, and industrial unrest in schools. I collected all items relating to the debate over 'secularism in the Republic' (to take the formulation adopted by the government-appointed Stasi Commission) ${ }^{2}$ from the daily newspaper Le Monde, the left-leaning monthly Le Monde Diplomatique, and the centre-left weekly Le Nouvel Observateur. I also collected postings to the Nouvel Observateur hosted web forum 'Are you for or against the banning of the Islamic veil at school?' (Forum 2003), part of a special edition devoted to 'France and the veil'.

Texts were selected to allow a comparison of representations from the 'serious' mainstream and centre-left press (occupying a dominant position within the media and political establishment, and heavily invested in the debate) with the personal views of readers. ${ }^{3}$ The more anonymous and unregulated Nouvel Observateur web forum was formed in a distinctive but dependent discursive domain; it contains responses to the dominant media framing by a self-selected group of readers.

In seeking the material effects of discourse and the wider dynamics of social power that discourse constitutes and is constituted by, it is important to acknowledge that 'the politics of discourse is often overdetermined by the power relationships which exist beyond the moment and the specific locality' (Kenway 1995, p. 44). The relationships under examination here are those tying the material conditions of the objects of an authoritative discourse (Muslim migrants) to the emergence and claims to legitimacy of that discourse (French republicanism). The current undertaking adopts Bourdieu's understanding of the relationship between representations and the distribution of a social field as

both the product and the stake of a permanent struggle between those, who, because of a position they occupy within the distributions, have 
an interest in subverting them by modifying the classifications in which they are expressed and legitimated, and those who have an interest in perpetuating misrecognition... (Bourdieu 1990, pp. 140-1)

I approach the debate as 'an instance of the system in action' (Denzin 1999, p. 110), looking for common themes, constructions and rhetorical strategies (Dijk 1993, Fairclough 1995, 2001, Riggins 1997, Stillar 1998).

This paper foremost seeks to identify the interests and historicise the dominant cultural logic(s) deployed by the political establishment to strengthen its control over the meanings and boundaries of the national space. The dominant framing presented in the texts considered below is that of French republicanism, and I begin therefore with some broad brushstrokes of this tradition before turning to a closer examination of the social position of Muslims in France and representations of the hijab.

\section{Order and disorder in the national space}

\section{The French republican model and its uses}

The French state stakes its claim to legitimacy on the identification of citizens who share the 'universal' values of equality, secularism and freedom offered by the Republic. Cultural and religious differences must be managed in order to preserve 'a space ordered by the common good alone, and open to all' (Benguigui and PeñaRuiz 2002). A 'free, secular, and compulsory' national education system is one of the key guarantors of republican values, and as such is the site of some of the hottest contestations of their content and taxonomy.

One of the founding functions of the national (and colonial) education system is the neutralisation of regional and religious allegiances through a uniform curriculum banning religious content and the use of any language other than French (Fanon 1970, Jennings 2000). This has been re-articulated in the current debate to respond to the new 'threat' to national unity.

Wearing a hijab to school has come to symbolise not only a breach of long accepted conditions of neutrality by the students themselves, but a threat to the very conditions of existence of the Republic, most notably, its exclusive right to a direct relationship with individuals as citizens, rather than through the state's rivals, intermediary communities and groups (Kepel 1994). At stake is 'control of the productive and reproductive functions of schooling' and hence the legitimate definition of society (Knight, Smith and Sachs 1990, p. 142). 
The official reason for the current vaguely worded administrative ban is that the hijab is an 'ostentatious' proselytising device (Pratt Ewing 2000). Currently, the hijab may be worn only 'if, after a period devoted to dialogue, the conflict persists' (Brizard 2003), while yarmulkes and crucifixes are less likely in the first instance to be considered ostentatious by school authorities (Pratt Ewing 2000, pp. 41-2).

However, with the inflammation of western anxieties about organised and political Islam, the hijab has become, by association, a matter not just of 'ostentatious' religious expression, but of public order and national security.

\section{All religions are equal...}

The historical opposition to church influence provides the authorising discourse for the debate outlined above. A strong but declining anticlerical tradition runs through postrevolutionary French politics, drawing inspiration from the eighteenth-century Enlightenment philosophers and encyclopaedists. The power and influence of the Catholic Church on the state and the loyalty of its citizens is an old point of contestation, particularly in relation to education. This is most notably expressed in the formal separation of church and state, including in matters of state education, in 1905, a time when the Third Republic was making the first moves towards mass primary education and training teachers as defenders of science to counterbalance the village priest.

Admittedly the threat posed by Catholicism has never been portrayed exactly as the current threat of Islam is by the mainstream media. The old distrust of religious power is now combined with fear of the formation of separatist communities. Government and press accusations of 'communitarianism' (AFP 2003b) indeed attribute a voluntary value not only to Islamic beliefs, but to the particular combination of social, residential and religious segregation many French Muslims experience. These accusations of separatism, coming from both sides of politics, are frequently expressed together with fears of 'tribalism' or 'balkanisation', creating a 'racialised' category (Jennings 2000). Prime Minister Raffarin is particularly concerned about what he terms 'ghettoisation': 'It is unacceptable that a teacher who enters a class should be able to say on this side are the Jews, on this side the Cathos, and on this side are the Muslims' (AFP 2003b).

This general statement masks the virtually exclusive political anxiety about France's five million Muslims, which in turn raises the question of why the massive educational stake of the Catholic Church rarely attracts the attention and tension it once did. Catholicism has only recently entered the ranks of republican respectability, the fait accompli of transfer from aristocratic to bourgeois dominance divesting it of the historical baggage of pro-royalist partisanship, its position unthreatening to the current distribution of state power. This is not to say that its power and influence is no longer 
felt, rather that it has largely melted into the vast pool of mythical neutrality and universality that constitutes a society's doxa (Bourdieu 1977).

Exemplifying this rapprochement is the funding of Catholic schools by the state (since 1959) and the successful campaign against increased state control over Catholic schools in 1984. The highpoint of this 'crusade to protect religious freedom' (Larkin 1997, p. 373) was a million-strong rally led by current French President Jacques Chirac, a vocal defender of secularism when it comes to the question of the hijab in schools.

Even at the historical height of anticlericalism, the state's attitude towards women and sexuality reflected religious customs and taboos. The freedom and equality that secularism claims to guarantee has broadened only recently to include concern for the position of women, and thereby frame moral objections to the position of women under Islam. No similar outcries about the viability of the French state arose from gendersegregated secondary schooling in the 1930s, when girls accounted for only a third of state enrolment, nor from the fact that women were without the vote until 1944, largely due to the opposition of secularists who feared women would be more influenced by the church than men and shift the balance of power (Larkin 1997, pp. 21-2).

We begin to see that the opposition between rationality and religious traditionalism is not as complete as it first appears and that the relationship between gender and power is complicated in this dilemma. The arguments aimed at increasing individual freedom from institutional sexual discrimination often resemble those used to support a ban on the hijab, which increases individual conformity before state institutions. This troublesome alignment confronts feminist thinkers, particularly Muslim feminist thinkers, who are, however, largely excluded from the mainstream press, powerful lobby groups and government commissions (Bloul 1997).

It is worth pausing to note some of these views. Many thinkers are concerned that western traditions of representing other cultures as inferior continue through the demonisation of gender practices (for a discussion see Sahaso 2003); others view this position as an abdication to cultural relativism (for example Nussbaum 1999). Investigations in France and elsewhere have found that most Muslim women, whether they wear the hijab or not, perceive prejudice as the primary source of their oppression, and Islam as providing rights and protection against oppression (Asmar 2001, Gaspard and Khosrokhavar 1995). In the current European climate some Muslim women view the hijab as a sign of non-conformity, rejecting assessments of themselves as 'passive victims' (Franks 2000, p. 920), and within Islam debates over the meaning and nature of requirements for women's attire date back to at least the ninth century (Wayland 1997). 
This paper is not concerned so much with the merits of arguments about any inherently repressive or liberating capacities of the hijab in itself, but rather with the processes and implications of symbolic investment.

\section{The social conditions of Islam in France}

Islam in France has historically provided both colonial sexual fantasies and paternalistic justifications for colonial domination (Bloul 1997, Silverman 1992). More recently Muslims have been the targets of an ascending far right whose politics have spilled into the mainstream through the hardening of legislation affecting migrants and the current focus on law and order, directly targeted at poor second generation youth.

Most Muslims currently living in France either arrived from North Africa and the Middle East in the booming postwar years, or are the children of this migration. In social and educational terms Islam is primarily located in the vast, dilapidated housing estates of the 1960s and 70s, where those who came to meet the demand for unskilled labour, and have suffered most from ongoing economic restructuring, have largely remained (Boulot and Boyson-Fradet 1984, Henriot-van Zanten 1992, van Zanten 1997). To give one example of this concentration, 78 per cent of Turkish migrants live in public housing estates where more than a third of residents are also migrants (Tribalat 1995, p. 126). The racialisation of (non-European) migration through the repetition of links between 'immigration, economic crisis, unemployment and the ideas of substitution and national preference' (Silverman 1992, p. 91) collapses the heterogeneous ethnicities, practices and beliefs encompassed by migrants to France. Racialised representations, as we shall see, simultaneously argue that equality is dependant on nationality and redefine French nationality to exclude Islam (the country's second largest religion!). The increasing importance of religion as a marker of ethnicity and foreignness since the 1980s contrasts with earlier periods when Islam was barely mentioned. Now it appears as the primary 'incompatibility' in the 'problem of migration' (De Wenden 1991).

The school district of Créteil exemplifies the underlying issues of social and ethnic segregation produced by the history of labour migration and economic restructuring. A recent government report identifies 'demoralised teachers, mediocre academic results, school violence, absenteeism, a high number of suspensions and expulsions' (Bronner 2003). In such areas with large migrant populations, high unemployment and schools in difficulty, better-off students are more likely to attend private schools or to travel out of the area to more distant state schools (Bronner 2003, Felouzis 2003). There is also evidence of discrimination against those of migrant background in the job market (Frickey and Primon 2002). 
When these patterns are considered, the interest of those in power in denying any difference or inequality other than that produced by chosen individual identity becomes obvious. This interest is increased by the fact that Islam here is more than an aspect of the current generation's heritage. A numerically small Islamic revival in the estates represents a political mobilisation appealing to a section of what Kepel calls 'this new proletariat of youth' (1994, p. 12). From the beginning of the 1990s, coinciding with the rise of the Front Islamique du Salut (Islamic Salvation Front) as the chief vehicle of opposition in Algeria, a section of the second generation of Muslim-background migrants in France has joined in a movement towards 'reIslamicisation'. This mobilisation has taken place during a period of decline in antiracist movements and the traditional left as effective voices for the marginalised (Kepel 1994, p. 211).

The polemic over the hijab in schools is therefore a site for the playing out of anxieties over ethnically and religiously coded 'social exclusion'. It is a displacement and deferral of a debate over the social consequences of a class divided society in which Muslim migrants occupy the bottom rung and an Islamic revival provides a point of opposition.

This is not to claim that ethnicity and class have melded together in French society. Rather, that the concentration in ageing housing estates of manual workers, many now unemployed, whose children face systematic scholastic disadvantage and labour market discrimination, belies the myth of equal citizenship. The political anxiety that this residentially segregated population will have no loyalty to the economic and political order which has failed it is manifested in the discourses surrounding immigration. Lack of loyalty to the French nation is postulated from 'alien' ethnic and religious loyalties. This slippage enables a recuperation of dispossessed non-migrant workers through the attribution their dispossession to the illegitimate claims of their neighbours. The failures of the French state to deal with the obvious and jarring emblems of social dislocation represented by the housing estates contribute to the desire for abstraction into debates problematising religion and race.

On the other hand, educated, cosmopolitan, middle-class migrants do not present the same problem, and indeed largely control representations of 'migrant' perspectives in the debate, joining the dominant discourse from positions within the state bureaucracy and higher education system.

In this section I have sketched in broad terms a dynamic of symbolic relations: the dialectic of the social realities of Muslims in France and the social representations that seek to define (and confine) them as a group. Further I have argued that a taxonomy is established within the category of 'migrant' that implies that working-class migrants 
could improve their lot if they would only throw off the shackles of Islamic fundamentalism and join an assimilationist middle-class model of the migrant.

\section{The structuring power of dominant representations}

The relatively unregulated realm of a web forum might be expected to throw up some radically opposing views to the dominant logic outlined above. In fact, digressions are relatively few. This discursive unity is doubtless partly a function of the location and audience of the forum, however a small number of participants do reject its formulation entirely:

I consider the problem of the veil to be a phoney debate. In the other European Union countries the question does not arise and moreover it only does in France when the media decides to turn a few problems found in certain schools into a newsflash. (Forum, Audrey, Lille, 21 May 2003). ${ }^{4}$

Such challenges frequently inspire a barrage of responses that structure the forum as a space where the exercise of control over the limits of discourse intersects with the distribution of social power (Fiske 1994). The conditions of participation are expressed through concern with identity and voice: ${ }^{5}$

You pretend not to be an Islamist? Who do you think we are? Take responsibility for yourself! You act clever: you pretend that you don't live on a housing estate. And yet, your language, your incoherent remarks don't appear to indicate that you belong to the privileged social strata even though you would like to make us believe it by playing arrogant. People of quality behave in keeping and have a polished tongue which is not your case. (Forum, Djamila, Paris, 27 May 2003)

More directly than in the press, forum interventions such as this reveal the limits governing speech in the debate. Digressions from the articulation of responses that are 'in keeping' simply result in incoherence.

However not all opposition is incoherent. Rather, there exists a surprising continuity in adherence to the dominant framing in contributions opposing the ban. Arguments from both sides of the debate tend not to challenge the standard terms, but rely on varying the standards, or re-shuffling the hierarchy of terms (such as freedom over equality): 
The main thing would be to agree on the very notion of secularism. To my mind, it is up to school to be secular, to know how to teach without taking sides and to open students up to the world ... If some girls wish to wear a headscarf, it's their problem. Displaying their belief will bring up questions and they will be able to ask themselves some too. And perhaps give up their headscarf. (Forum, Vero, Toronto, 21 May 2003)

\section{Othering at home/saming at school}

A closer examination of some of the consistent features of the debate shows that the apparent discursive coherence of republican arguments is indeed unstable. Arguments against the hijab at school depend heavily on drawing apart cases that can only be maintained as distinct when presented at a carefully guarded level of abstraction. One such is the distinction between the claims and freedoms of public and private space. It is frequently pointed out in the Nouvel Observateur forum that Muslims are free to wear the hijab at home, but that the state cannot support the physical display of alien private (collective) value systems at school, other than the one disseminated by the school:

Secularism neither can nor should accept signs of religious affiliation such as the headscarf, yarmulke, or cross. It is true that for the Christian world, the sight of a cross is less shocking. This Christian symbol does not necessarily evoke or lay claim to a particular affiliation. However, for the sake of appeasement, the fundamental spirit of secularism consists of always making sure that religion is kept outside of the sphere of the Republic, everyone should, however, be able to have the freedom to exercise their religion. In a word, I am against the wearing of the headscarf at school. (Forum, Ayrel, Langon, 23 May 2003, emphasis added)

Only the hijab is assumed to reflect a moral regime and personal comportment that is in conflict with accepted norms (republican values), particularly freedom.

In a second contribution, the distinctions between the hijab, an overdetermined signifier, and 'mere' signs of religion justify a ban exclusively on the hijab:

Signs of religion like the Christian cross, the hand of Fatima and the cross of David are allowed at school, and so much the better. The headscarf is much more than that. And to my knowledge, no French Jew ever caused a mini-revolution and called out the press because he was requested to remove his yarmulke, which is also proof of a different approach. (Forum, Stéphanie, London, 27 May 2003) 
This view of the wearing of the hijab as an act of violent defiance, if only because it attracts public attention, also reflects the initial declaration of the hijab as 'provocative' by the Conseil d'Etat (State Council) following the 1989 'affair of the veil'.

Since the hijab has continued to reappear at school gates in the fifteen years following this judgement, press commentators now demand reassurance that the hijab is not becoming so acceptable amongst the current generation that those who do not wear it will become ostracised (Fohr, Vigoureux, Monnin and des Deserts 2003). Among the many gendered claims levelled against 'these girls' is that they have been brainwashed, are only wearing it as a fashion statement, or are trying to seduce boys with their mystique. The latter two views have gained prominence since the more recent banning of two well-off sisters with secular parents, who confound the stereotype of submissive instruments of extremists (Dhombres 2003).

The crux of the matter is that the hijab represents not merely a playful or consumercapitalist allegiance, but one to an unknown and potentially dangerous religion with a corporate power the state cannot admit in public. In fact, the state must theoretically admit Islam as a private and individual practice as long as it remains symbolically invisible in the exclusively 'republican' domain of the school.

One way to do this is to create mechanisms for self-regulation, such as the statesponsored French Council of Islam, which Prime Minister Jean-Pierre Raffarin, intends to act as 'the enlightened voice of the Islam of France to combat the drifting which could menace our social cohesion' (AFP 2003a).

In the Nouvel Observateur forum, the political character of the 'drifting', accompanied by the spectre of a foreign conspiracy, is demonstrated by a purported shift from a familiarly coded model of (male) youthful rebellion to a newly organised and coercive one:

Fifteen or twenty years ago, the young people from the suburbs identified with American rappers, had more fun, drank alcohol like all youth. Now they don't go out, 'police' the North African girls of the estate, and tend to let themselves be indoctrinated. I think this shift is more political than religious, and is the product of the underlying work of Islamist movements ... financed by the Middle East. The emergence of such attitudes should be watched and restricted, precisely by a ban on the veil at school. (Forum, Ivan, Montpellier, 20 May 2003)

The confusion of particular and general arguments in favour of the ban reveals a general ambivalence. The two prongs consist of an appeal to the principle of a formal 
absence of all religion in schools, and a widely held view that Islam is an oppressive religion that is also politically threatening.

\section{Social power and morality}

Socially powerful moral orders are able to make themselves invisible and universal (doxic) while socially subordinate moral regimes, even when they are similar in content, are represented as partisan and thus excluded from the realm of "public order'. The fiction that the absence of religious or ideological influence in school is guaranteed by a restricted western dress code requires belief in the fiction that coercive exterior signs of social identity are only present in the dress of limited ('eastern') religious customs.

For this to be done with a clean conscience, that is, to guarantee the efficacy of the 'symbolic violence' (Bourdieu 1977), the hijab must first be understood as an imposed stigmatisation before it can be removed in the name of equality and freedom. The weekly Le Nouvel Observateur contributes to this process in its framing of the story told to a journalist by Hamel, an 'unveiled woman':

I had a Moroccan friend, who had a son. He spent so much time hanging around outside that Tabligh preachers ended up converting him. They talked to him about the end of the world. Enlisted the kid. One day, he came home, he yelled at his mother because she didn't wear the veil. Not pious enough. Then he told her that this world disgusted him, he'd had enough, he was going to die for God. And he threw himself from the fourth storey window ... By shutting yourself off, you go crazy and destroy yourself. (Vigoureux 2003)

The journalist structuring the narrative jumps to the real point of the story: Hamel decides to remove her hijab as a consequence of her friend's experience.

In joining the above incident to the 'unveiling' with no other context, the article seeks to demonstrate a link between the ultimate source of anxiety - brainwashed separatist delinquents - and the hijab. Desperation is depicted as overflowing into religious sentiment, the last refuge of the weakened, one into which they are enticed by extremists and which destroys their authentic selfhood.

The description of Hamel's own life before she stopped wearing the veil can only be understood as a self-imposed choice whose consequences are the product of the inherent characteristics of Islam. Under the hijab: 
no more mixing of the sexes, no more employment, meetings every Sunday reserved for Muslim sisters ... Hamel had the feeling of being cut off from other 'citizens', of sacrificing her French identity for her faith. (Vigoureux 2003)

Islam, defined by the self-regulating power of the hijab, is established as conformity to a single set of cultural practices, whose isolationist tendencies are an argument for strengthening a countervailing individual conformity before the state. Disloyal conformity to Islam goes beyond faith to what Hamel tells Le Nouvel Observateur is 'an exclusive, separate world, where difference has no place', a 'counter-society for which Islam seems only to be the pretext' (Vigoureux 2003).

The presentation of Hamel's self-confession as an unveiled woman is important because it allows the article's silences and abbreviations to reduce, or transpose, her experiences of a religiously coded social isolation and social dislocation to the hijab. This process of symbolic investment in the hijab works through the establishment of binary oppositions (Table 1), some of which occasionally swap places in arguments against the ban. I wish to finish with an examination of the last of these.

\begin{tabular}{cc}
\hline Republicanism & Islam \\
\hline Secular & Religious \\
Rational & Irrational \\
Citizenship & Group membership \\
Freedom & Submission \\
Enlightened & Medieval \\
Civilised & Barbaric \\
Equality & Inequality \\
Specific to French nation & Alien to French nation \\
Inclusive & Exclusive \\
Universal & Partial \\
Tolerant & Intolerant \\
Open & Closed \\
\hline Host & Guest \\
\hline
\end{tabular}

Table 1: Oppositions common to press articles and the Nouvel Observateur online debate 


\section{Guests and hosts: some duties and obligations}

Le Monde reports that Interior Minister Nicolas Sarkozy wishes to steer 'Islam in France' towards being 'Islam of France' in order to 'bring it out of the obscurity to which it has been confined for too long' (Gautier 2003). For the moment, though, 'French Islam' is almost oxymoronic. Similarly, religious affairs commentator Xavier Ternisien is at pains to distinguish between foreign 'Muslims of France' and naturalised 'French Muslims' (Ternisien 2003a).

Once again, the relative social positions of subject and object come to the fore in web forum contributions:

Of French origin, $I$ have nothing against Islam ... as long as French laws are respected, those who wish to mark themselves off from our secularism, respected up to now, can just go back home, nobody is forcing nobody, each does as they want at home ... the headscarf is just a provocation by some and so as not to look bad others follow. (Forum, Jean, Nice, 20 May 2003, emphasis added)

Analysing the constructs of the nation-state, Abdelmalek Sayad suggests that there is an extra obligation to respect the established order when one is 'foreign to this order, its history, the history of its genesis and its functioning, its ethics, its morality, its value system; one must submit to it, one owes it respect and obedience' (Sayad 1999, p. 9).

What appear to be sacrifices owed out of politeness amount in fact to political abdications. The rules of hospitality are evident in a more depersonalised form in Jean Daniel's editorial in the same edition of the Nouvel Observateur. 'The Republic provokes no one. It is defending itself. It does not wish to impose anything on anyone. It simply wants to share its traditions with those who wish to live in it' (Daniel 2003).

'What shocks, irritates and disconcerts', continues Daniel,

is the affirmation of a collective difference and a belonging to a community exterior to the nation. What shocks, irritates and disconcerts is that the guests of a state do not have the politeness to respect the laws, and above all the struggles, of their hosts. (Daniel 2003)

Sayad's analysis of frontier demarcation and national order explains some of the unease expressed in Daniel's editorial: 
The presence in the heart of the nation of 'non-nationals' ... perturbs and troubles the established order of this separation, disturbing the integrity of this order, its purity or mythical perfection, and thus the full accomplishment of the implicit logic of this order. (Sayad 1999, p. 6)

The children of migrants are the most embarrassing guests, because they are also products of national mechanisms of cultural reproduction and integration and so represent a disturbing rupture in the national-migrant dichotomy (Sayad 1999, pp. 12-13). It is interesting in this regard to note the haste of a middle-class section of the second generation active in the political mainstream to make reassurances of their loyalty through the proposal of a 'French Council of Secular Muslims' supporting the ban on the hijab (Ternisien 2003b).

In gaining such reassurances the republican order benefits from the conflict. When founding principles are challenged, the moment of reaffirmation exposes their logic, but also provides an opportunity to strengthen a relationship of domination. In giving Islam a relationship of incompleteness, anomaly and even anomy with regards to the categories of 'state thought' (Sayad 1999, pp. 12-13), an ontological fault is tied to all other judgments of deviance and digression.

\section{Conclusion}

French republicanism masks relations of subordination through the formal imposition of undifferentiated conditions for all citizens, even as the differentiated objects of its application allow its ideological foundations to be traced.

This ideology rests on the fiction of an absence of corporate interests - religious or other - in public life. The symbolic violence enacted by appeals to a socially and culturally neutral republican model depends on the model's elevation above the specific historical and material conditions of its generative context and subsequent deployments and appropriations. The existence of signs of difference tied to inequality provides grounds for offence in the presence of claims of unified equality. As a threat to the coherence of citizenship, materially and socially subordinated migrants are the objects of special attention aimed at drawing them back into the undifferentiated national body.

The hijab is an at once visible and elusive expression of heterodoxy. Its transgressive power is as a reminder of the embarrassing turn by a generation expected to 'integrate', or at worst to fall into the disorganised and familiar delinquency of the underprivileged, towards an expanding alternative symbolic order. The history of anticlericalism in France authorises intervention even as it has lost the ability to divide the polity within itself. 
Removing markers, symbolically invested as representations of counter-state allegiances, from the core spheres for the reproduction of republican values provides a discursive stage for reaffirming the legitimacy of state claims over populations as citizens who are alike. Campaigns against the hijab present Islam to migrants as a mark of disrespect to the French nation. Once this accusation has been levelled, it is up to the transgressors to reassure the political establishment of their neutrality, moral fibre and good manners; their conformity as individuals and their disappearance as a group or, rather, their silence and invisibility in the public space of the nation.

\section{Notes}

1 The words 'foulard' (scarf/headscarf) and 'voile' (veil) are the most commonly used in France to describe the various types of covering worn by some Muslim women. The semantic politics of the various terminologies have been addressed elsewhere (Siblot 1992). I have chosen the Arabic 'hijab' because it is widely used in English and acknowledges the specificity of the veil under question, referring specifically to the scarf covering the hair and neck.

2 All translations from French are my own unless otherwise attributed.

3 From over 1926 web postings a sample of 200 was included in the analysis. Single postings were selected at random. Other postings with which the initial item engaged and items that subsequently engaged with the initial posting were then considered together. In most instances 'strings' of postings extended from between two and ten contributions, and often involved repeated interventions by the same individuals. I have been guided in my methodology by recent developments in web-based research (Mann and Stewart 2000, Sharf 1999).

4 In translating forum contributions I have not attempted to correct the fluid punctuation and syntax of electronic communication.

5 For this reason, original web aliases have been retained. This decision has been taken with regard for the ethical debates around anonymity (Mann and Stewart 2000, Sharf 1999) based on the public nature of the forum, the limited use of direct quotations, translation into English, and the benefits of retaining identity claims. Although identity claims are to be treated with caution, they do enhance the picture that emerges: if authors are to be believed, most write from within France, with a smaller participation from North Africa and Canada, where greater opposition to a ban and resistance to the dominant logic is to be found. Of those whose gender can be identified, women easily outnumber men, the inverse of public interventions in print media.

\section{References}

AFP (2003a) Dalil Boubakeur a été élu président du Conseil Français du Culte Musulman, Le Monde, 4 May, viewed online 5 May 2003, <http://www.lemonde.fr/> 
AFP (2003b) Jacques Chirac défend le principe de laïcité, Le Monde, 22 May, viewed online 22 May 2003, <http://www.lemonde.fr/>

Asmar, C. (2001) A community on campus: Muslim students in Australian universities, in S. Akbarzadeh and A. Saeed, eds., Muslim Communities in Australia, UNSW Press, Sydney.

Benguigui, Y. and H. Peña-Ruiz (2002) L'exigence laïque du respect mutuel, Le Monde Diplomatique, January, viewed online 25 June 2003, <http://www.mondediplomatique.fr/, accessed 25 June 2003>

Bloul, R. (1997) Victims or offenders? Other women in French sexual politics, in K. Davis, eds., Embodied Practices: Feminist Perspectives on the Body, Sage Publications, London.

Bone, P. (2004) Why teachers must not wear the burqa in our schools, The Age, 25 January, p. 11.

Boulot, S. and D. Boyson-Fradet (1984) L'échec scolaire des enfants de travailleurs immigrés (un problème mal posé), Les Temps Modernes, vol. 452-4, pp. 1902-14.

Bourdieu, P. (1977) Outline of a Theory of Practice, Cambridge University Press, Cambridge and New York.

Bourdieu, P. (1990) The Logic of Practice, Stanford University Press, Stanford, Calif.

Brizard, C. (2003) École: légiférer ou pas?, Le Nouvel Observateur, 15 May, viewed online 15 May 2003, <http://www.nouvelobs.com/articles/p2010/index2.html>

Bronner, L. (2003) L'académie de Créteil concentre les maux de l'école en banlieu, Le Monde, 23 April, viewed online 24 April 2003, <http://www.lemonde.fr/>

Daniel, J. (2003) Décidément, non au voile!, Le Nouvel Observateur, 15 May, viewed online 16 May 2003, <http://www.nouvelobs.com/articles/p2010/index2.html>

De Wenden, C. W. (1991) North African immigration and the French political imaginary, in M. Silverman, eds., Race, Discourse and Power in France, Avebury, Aldershot.

Denzin, N. K. (1999) Cybertalk and the method of instances, in S. Jones, ed., Doing Internet Research: Critical Issues and Methods for Examining the Net, Sage Publications, Thousand Oaks, CA.

Dhombres, D. (2003) Télévision: voile ou piercing, Le Monde, 3 November, viewed online 12 November 2003, <http://www.lemonde.fr>

Dijk, T. A. v. (1993) Elite Discourse and Racism, Sage Publications, Newbury Park, Calif. Fairclough, N. (1995) Critical Discourse Analysis: The Critical Study of Language, Longman, London and New York.

Fairclough, N. (2001) Language and Power, Longman, Harlow, Eng. and New York.

Fanon, F. (1970) A Dying Colonialism, Penguin Books, Harmondsworth.

Felouzis, G. (2003) La ségrégation ethnique au collège et ses conséquences, Revue Française de Sociologie, vol. 44, no. 3, p. 413.

Fiske, J. (1994) Audiencing: cultural practice and cultural studies, in N. K. Denzin and Y. S. Lincoln, eds., Handbook Of Qualitative Research, Sage Publications, Thousand Oaks. 
Fohr, A., E. Vigoureux, I. Monnin and S. des Deserts (2003) Enquête sous le voile, Le Nouvel Observateur, 15 May, viewed online 16 May 2003, $<$ http://www.nouvelobs.com/articles/p2010/index2.html>

Forum (2003) Etes-vous pour ou contre l'interdiction du foulard islamique à l'école? (Are you for or against the banning of the Islamic veil at school?), Le Nouvel Observateur, viewed May-June 2003, $<$ http://permanent.nouvelobs.com/cgi/debats/aff_mess?id=200203250173>

Franks, M. (2000) Crossing the borders of whiteness? White Muslim women who wear the hijab in Britain today, Ethnic and Racial Studies, vol. 23, no. 5, pp. 917-29.

Frickey, A. and J.-L. Primon (2002) Jeunes issus de l'immigration: les diplômes de l'enseignement supérieur ne garantissent pas un égal accès au marché du travail, Formation Emploi, vol. 79, pp. 31-49.

Gaspard, F. and F. Khosrokhavar (1995) Le Foulard et la République, La Découverte, Paris.

Gautier, A. (2003) Jean-Pierre Raffarin charge le Conseil Français du Culte Musulman d'un 'rôle modérateur auprès des jeunes', Le Monde, 5 May, viewed online 6 May 2003, <http://www.lemonde.fr>

Henriot-van Zanten, A. (1992) Immigrants and schools in France: recent changes in policy and research. Paper presented at the Annual Meeting of the American Educational Research Association, San Francisco, 20-24 April.

Jennings, J. (2000) Citizenship, republicanism and multiculturalism in contemporary France, British Journal of Political Science, vol. 30, no. 4, p. 575.

Kenway, J. (1995) Having a postmodernist turn or postmodernist angst: a disorder experienced by an author who is not yet dead or even close to it, in R. Smith and P. Wexler, eds., After Postmodernism: Education, Politics and Identity, Falmer Press, London.

Kepel, G. (1994) A lOuest d Allah, Seuil, Paris.

Knight, J., R. Smith and J. Sachs (1990) Deconstructing hegemony: multicultural policy and a populist response, in S. J. Ball, ed., Foucault and Education: Disciplines and Knowledge, Routledge, London and New York.

Larkin, M. (1997) France Since the Popular Front: Government and People, 1936-1996, Clarendon Press, Oxford and New York.

Limage, L. (2000) Education and Muslim identity: the case of France, Comparative Education, vol. 36, no. 1, pp. 73-94.

Mann, C. and F. Stewart (2000) Internet Communication and Qualitative Research: A Handbook for Researching Online, Sage, London.

Nussbaum, M. C. (1999) Sex and Social Justice, Oxford University Press, New York.

Pratt Ewing, K. (2000) Legislating religious freedom: Muslim challenges to the relationship between 'church' and 'state' in Germany and France, Daedalus, vol. 129, no. 4, pp. 31-54. 
Riggins, S. H. (1997) The Language and Politics of Exclusion: Others in Discourse, Sage Publications, Thousand Oaks, Calif.

Sahaso, S. (2003) Culture, tolerance and gender: a contribution from the Netherlands, European Journal of Women's Studies, vol. 10, no. 1, pp. 7-27.

Sayad, A. (1999) Immigration et pensée d'état, Actes de la Recherche en Sciences Sociales, vol. 129, pp. 5-14.

Sharf, B. (1999) Beyond netiquette: the ethics of doing naturalistic discourse research on the internet, in S. Jones, ed., Doing Internet Research: Critical Issues and Methods for Examining the Net, Sage Publications, Thousand Oaks, Calif.

Siblot, P. (1992) Ah! Qu'en termes voilés ces choses-la sont mises, Mots: Les Langages du Politique, vol. 30, pp. 5-17.

Silverman, M. (1992) Deconstructing the Nation: Immigration, Racism, and Citizenship in Modern France, Routledge, London and New York.

Stillar, G. F. (1998) Analyzing Everyday Texts: Discourse, Rhetoric, and Social Perspectives, Sage Publications, Thousand Oaks, Calif.

Ternisien, X. (2003a) tre musulman en France (2/2), Le Monde, 29 April, viewed online 30 April 2003, <http://www.lemonde.fr>

Ternisien, X. (2003b) Les élites musulmanes à la recherche d'une représentation laïque, Le Monde, 20 May, viewed online 21 May 2003, <http://www.lemonde.fr>

Tribalat, M. (1995) Faire France: Une Enquête sur les Immigrés et Leurs Enfants, La Découverte, Paris.

van Zanten, A. (1997) Schooling immigrants in France in the 1990s: success or failure of the republican model of integration, Anthropology and Education Quarterly, vol. 28, no. 3, pp. 351-74.

Vigoureux, E. (2003) Paroles de dévoilées, Le Nouvel Observateur, 15 May, viewed online 16 May 2003, <http://www.nouvelobs.com/articles/p2010/index2.html>

Wayland, S. (1997) Religious expression in public schools: kirpans in Canada, hijab in France, Ethnic and Racial Studies, vol. 20, no. 3, pp. 545-61. 